University of Nebraska - Lincoln

DigitalCommons@University of Nebraska - Lincoln

USGS Staff -- Published Research

US Geological Survey

2003

\title{
Age of the Mono Lake excursion and associated tephra
}

\author{
Larry Benson \\ University of Colorado at Boulder, great.basin666@gmail.com \\ Joseph Liddicoat \\ Barnard College \\ Joseph Smoot \\ US Geological Survey \\ Andrei Sarna-Wojcicki \\ US Geological Survey \\ Robert M. Negrini \\ California State University - Bakersfield, rnegrini@csub.edu
}

See next page for additional authors

Follow this and additional works at: https://digitalcommons.unl.edu/usgsstaffpub

Part of the Geology Commons, Oceanography and Atmospheric Sciences and Meteorology Commons, Other Earth Sciences Commons, and the Other Environmental Sciences Commons

Benson, Larry; Liddicoat, Joseph; Smoot, Joseph; Sarna-Wojcicki, Andrei; Negrini, Robert M.; and Lund, Steve, "Age of the Mono Lake excursion and associated tephra" (2003). USGS Staff -- Published Research. 785.

https://digitalcommons.unl.edu/usgsstaffpub/785

This Article is brought to you for free and open access by the US Geological Survey at DigitalCommons@University of Nebraska - Lincoln. It has been accepted for inclusion in USGS Staff -- Published Research by an authorized administrator of DigitalCommons@University of Nebraska - Lincoln. 


\section{Authors}

Larry Benson, Joseph Liddicoat, Joseph Smoot, Andrei Sarna-Wojcicki, Robert M. Negrini, and Steve Lund 


\title{
Age of the Mono Lake excursion and associated tephra
}

\author{
Larry Benson $^{\mathrm{a}, *}$, Joseph Liddicoat ${ }^{\mathrm{b}}$, Joseph Smoot ${ }^{\mathrm{c}}$, Andrei Sarna-Wojcicki ${ }^{\mathrm{d}}$, \\ Robert Negrini ${ }^{\mathrm{e}}$, Steve Lund $^{\mathrm{f}}$ \\ a Arid Regions Climate Project, US Geological Survey Suite E127, 3215 Marine Street, Boulder, CO 80303, USA \\ ${ }^{\mathrm{b}}$ Department of Environmental Science, Barnard College, Columbia University, New York, NY 10027, USA \\ ${ }^{\mathrm{c}}$ US Geological Survey, MS 955, Reston, VA 22092, USA \\ ${ }^{\mathrm{d}}$ US Geological Survey, MS 975, 345 Middlefield Road, Menlo Park, CA 94025, USA \\ ${ }^{\mathrm{e}}$ Department of Physics and Geology, California State University, Bakersfield, CA 93311, USA \\ ${ }^{\mathrm{f}}$ Department of Earth Sciences, University of Southern California, Los Angeles, CA 90089, USA
}

Received 30 September 2002; accepted 31 October 2002

\begin{abstract}
The Mono Lake excursion (MLE) is an important time marker that has been found in lake and marine sediments across much of the Northern Hemisphere. Dating of this event at its type locality, the Mono Basin of California, has yielded controversial results with the most recent effort concluding that the MLE may actually be the Laschamp excursion (Earth Planet. Sci. Lett. 197 (2002) $151)$. We show that a volcanic tephra (Ash \#15) that occurs near the midpoint of the MLE has a date (not corrected for reservoir effect) of 28,620 $\pm 300{ }^{14} \mathrm{C}$ yr BP $(\sim 32,400$ GISP2 yr BP) in the Pyramid Lake Basin of Nevada. Given the location of Ash $\# 15$ and the duration of the MLE in the Mono Basin, the event occurred between 31,500 and 33,300 GISP2 yr BP, an age range consistent with the position and age of the uppermost of two paleointensity minima in the NAPIS-75 stack that has been associated with the MLE (Philos. Trans. R. Soc. London Ser. A 358 (2000) 1009). The lower paleointensity minimum in the NAPIS-75 stack is considered to be the Laschamp excursion (Philos. Trans. R. Soc. London Ser. A 358 (2000) 1009).

Published by Elsevier Science Ltd.
\end{abstract}

\section{Introduction}

The Mono Lake excursion (MLE) is a paleomagnetic time marker that is useful in correlating records of climate change over a large part of the Northern Hemisphere. It has been found in lacustrine sediments from the Great Basin of western North America, e.g. Liddicoat and Coe (1979), Negrini et al. (1984), Liddicoat (1992) and in marine sediments from the Atlantic and Arctic Oceans (Nowaczyk, 1997; Nowaczyk and Knies, 2000).

At its type locality, the MLE has two different patterns that straddle a volcanic tephra (Ash \#15) within the Wilson Creek Formation. The MLE begins $\sim 15 \mathrm{~cm}$ below and ends $\sim 15 \mathrm{~cm}$ above Ash $\# 15$, with the most negative inclination occurring $10 \mathrm{~cm}$ below the tephra. The lower part of the excursion is characterized by a westerly declination (towards $\sim 300^{\circ}$ ) when the inclina-

*Corresponding author. Tel.: + 1-303-541-3005; fax: + 1-303-4472505 .

E-mail address: 1benson@usgs.gov (L. Benson). tion is negative $\left(\sim-30^{\circ}\right)$ and the relative field intensity is low. The upper part of the excursion is characterized by an easterly declination (towards $\sim 100^{\circ}$ ) when the inclination approaches $+90^{\circ}$ and when the relative intensity is high (Coe and Liddicoat, 1994). Magnetic intensity varied during the MLE; however, the event occurred throughout a time interval characterized by a generally low intensity (see Fig. 6 in Benson et al., 1998).

Two sediment cores from Summer Lake, Oregon, contain the entire MLE (Negrini et al., 2000); however, only the upper half of the MLE occurs in sediments from the Pyramid Lake and Carson Desert Basins of western Nevada (Liddicoat, 1992). The Carson Sink tephra (Davis, 1978) has been found in association with the MLE at the Carson Sink site in the Carson Desert Basin (Liddicoat, 1992) and at the Pelican Point site in the Pyramid Lake Basin (Liddicoat, 1996) (Fig. 1A). Ash $\# 15$ and the Carson Sink tephra have nearly identical chemical compositions, indicating that they are the same tephra. The unique chemical composition of Ash \#15 allows it to be distinguished from other tephras in the Mono Basin (Table 1). Hereafter, we refer 


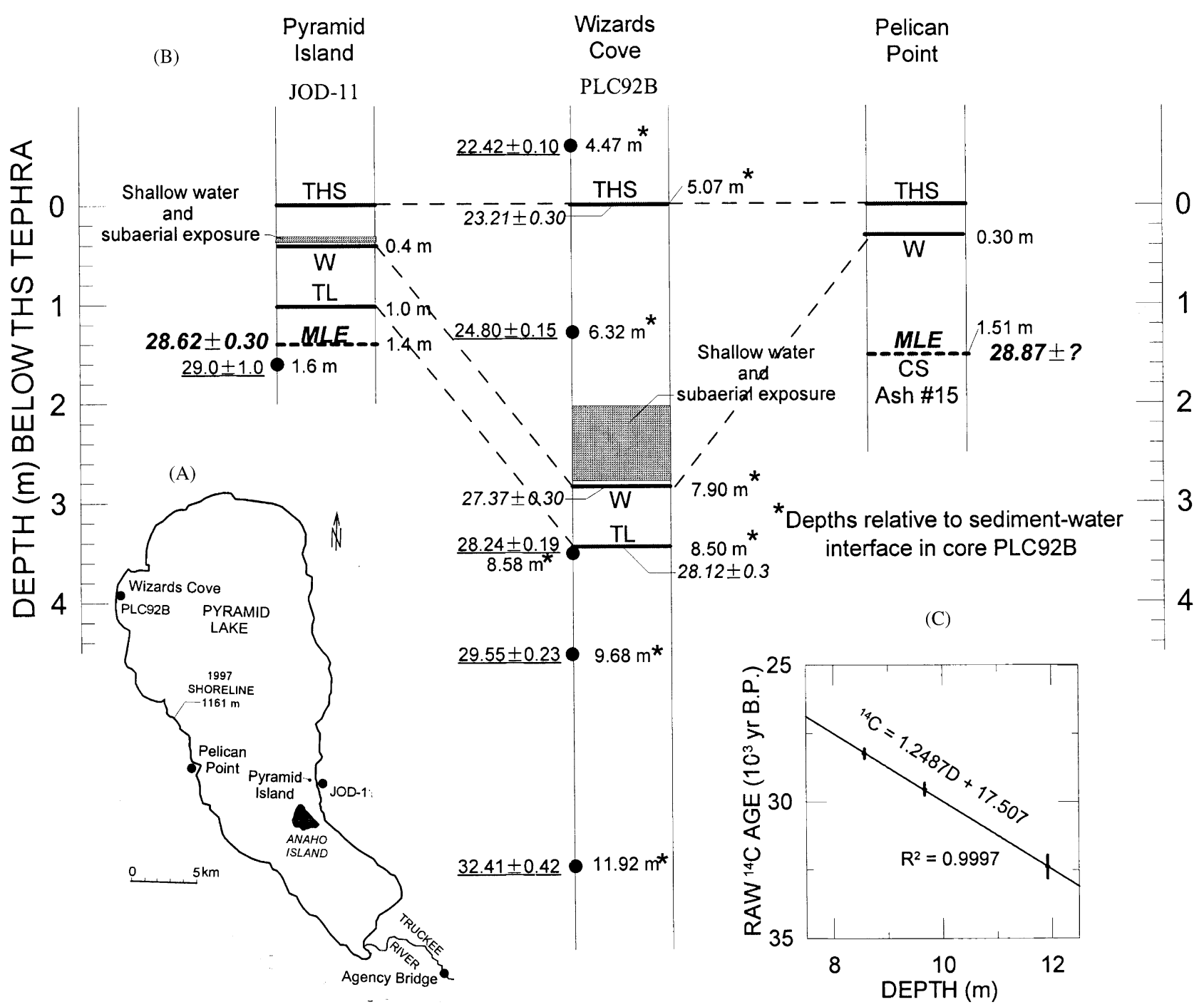

Fig. 1. (A) Sites in the Pyramid Lake Basin at which tephra and the Mono Lake excursion have been found. Magnetic measurements that would indicate the position of the MLE were not done on PLC92B. (B) ${ }^{14} \mathrm{C}$ data and the positions of the Trego Hot Springs (THS), Wono (W), Timber Lake (TL), Carson Sink (CS)/Mono Lake Ash $\# 15$ tephra, and the upper half of the MLE. Measured ${ }^{14} \mathrm{C}$ dates $\left({ }^{14} \mathrm{C}\right.$ yr $\left.\mathrm{BP}\right)$ are underlined; calculated dates (units yr BP) are not. Radiocarbon dates have not been corrected for a reservoir effect. Depths at the Pyramid Island and Pelican Point sites are given relative to the THS which has been assigned a depth of $0.0 \mathrm{~m}$. Depths in the PLC92B core (Wizards Cove) are given relative to the sedimentwater interface. (C) Age model used in the calculation of the ${ }^{14} \mathrm{C}$ ages of the Wono (W) and Timber Lake (TL) tephra found in core PLC92B.

to the tephra that occurs within the MLE by its earliest designation (Ash \#15).

A record of relative paleomagnetic field intensity for the North Atlantic region has been constructed by integrating magnetic data from six marine sediment cores (NAPIS-75 stack). The stacked record was linked to the GISP2 age model by correlation of the marine planktonic $\delta^{18} \mathrm{O}$ record to the GISP2 ice-core $\delta^{18} \mathrm{O}$ record (Laj et al., 2000). An intensity low centered at $\sim 34,500$ GISP2 yr BP in the NAPIS-75 stack identified by Laj et al. (2000) as the MLE has also been linked to a distinct perturbation in the ${ }^{36} \mathrm{Cl}$ flux rate between Dansgaard-Oeschger (D-O) events 6 and $7(32,800$ and 34,500 GISP2 yr BP) in the GRIP ice core (Wagner et al., 2000). The perturbation in the ${ }^{36} \mathrm{Cl}$ flux rate occurred between $\sim 33,400$ and $\sim 34,500$ GISP2 yr BP and peaked at 34,100 GISP2 yr BP

In the GRIP ice core, the paleomagnetic intensity low and increased production of ${ }^{36} \mathrm{Cl}$ associated with the Laschamp excursion occur between $\sim 38,500$ and $\sim 43,000$ GISP2 yr BP and the maximum in ${ }^{36} \mathrm{Cl}$ production occurs at $\sim 40,700$ GISP2 yr BP The assignment of this age range to the Laschamp excursion is broadly consistent with earlier age determinations for the volcanic flow that contains the excursion, recognizing that GISP2 ages are not equivalent to isotopically determined ages. For example, Hall and York (1978) obtained whole rock $\mathrm{K}-\mathrm{Ar}$ and ${ }^{40} \mathrm{Ar} /{ }^{39} \mathrm{Ar}$ ages of 47,400 \pm 1900 and 45,400 $\pm 2500 \mathrm{yr} \mathrm{BP}$, and Gillot et al. (1979) obtained a K/Ar date of $43,000 \pm 5000 \mathrm{yr} \mathrm{BP}$ as 
Table 1

Selected electron-microprobe and instrumental neutron-activation analyses of Wilson Creek (WC) and Carson Sink (CS) tephra beds

\begin{tabular}{|c|c|c|c|c|c|c|c|c|c|}
\hline Ash No. & $\mathrm{K}$ & $\mathrm{Sc}$ & $\mathrm{Co}$ & $\mathrm{Ba}$ & $\mathrm{La}$ & $\mathrm{Ce}$ & $\mathrm{Eu}$ & $\mathrm{Yb}$ & $\mathrm{U}$ \\
\hline WC\#1 & 4.62 & 1.79 & 0.21 & $<35$ & 19.0 & 42.7 & 0.18 & 2.80 & 6.12 \\
\hline $\mathrm{WC} \# 2$ & 0.69 & 13.30 & 23.40 & 477 & 14.5 & 31.9 & 1.17 & 1.28 & 0.24 \\
\hline $\mathrm{WC} \# 3$ & 3.68 & 1.69 & 0.13 & 47 & 12.4 & 28.5 & 0.14 & 2.94 & 7.28 \\
\hline $\mathrm{WC} \# 4$ & 3.54 & 1.64 & 0.10 & 42 & 11.9 & 26.8 & 0.13 & 3.04 & 7.30 \\
\hline $\mathrm{WC} \# 5$ & 3.87 & 1.70 & 0.15 & 88 & 19.5 & 39.9 & 0.22 & 2.52 & 6.39 \\
\hline $\mathrm{WC} \# 6$ & 3.87 & 1.73 & 0.15 & 64 & 19.6 & 41.3 & 0.22 & 2.71 & 6.64 \\
\hline $\mathrm{WC} \# 7$ & 3.82 & 1.70 & 0.15 & 58 & 19.5 & 41.2 & 0.20 & 2.62 & 6.60 \\
\hline $\mathrm{WC} \# 8$ & 3.98 & 1.57 & 0.13 & 52 & 14.9 & 33.9 & 0.20 & 2.69 & 6.92 \\
\hline WC\#9 & 3.97 & 1.48 & 0.12 & 86 & 16.9 & 33.9 & 0.23 & 2.51 & 6.22 \\
\hline $\mathrm{WC} \# 10$ & 3.70 & 1.67 & 0.13 & 104 & 16.0 & 32.0 & 0.24 & 2.62 & 6.78 \\
\hline WC\#11 & 3.82 & 1.51 & 0.12 & 85 & 14.8 & 30.7 & 0.21 & 2.64 & 6.68 \\
\hline$W C \# 13$ & 3.93 & 1.54 & 0.14 & 45 & 13.4 & 30.5 & 0.20 & 2.68 & 6.52 \\
\hline WC\#14 & 3.78 & 1.53 & 0.16 & 78 & 15.6 & 33.2 & 0.22 & 2.58 & 6.39 \\
\hline WC\#15 & 4.53 & 1.81 & 0.22 & 161 & 22.2 & 54.1 & 0.27 & 2.37 & 6.00 \\
\hline$W C \# 16$ & 3.72 & 2.26 & 0.13 & 40 & 12.3 & 23.5 & 0.19 & 2.70 & 8.34 \\
\hline WC\#17 & 4.13 & 2.12 & 0.47 & 46 & 18.5 & 35.9 & 0.23 & 2.45 & 6.39 \\
\hline$W C \# 19$ & 4.60 & 2.03 & 0.22 & 77 & 15.8 & 33.5 & 0.26 & 2.42 & 6.49 \\
\hline CS & 4.42 & 1.87 & 0.20 & 164 & 20.8 & 45.7 & 0.27 & 2.45 & 6.17 \\
\hline
\end{tabular}

Numbers in bold and italics indicate compositions that are similar to WC Ash $\# 15$. Concentrations in $\mu \mathrm{g} \mathrm{g}^{-1}$, except for K, which is in weight percent.

well as a thermoluminescence date of $44,100 \pm 6500 \mathrm{yr}$ BP for the Laschamp flow.

\section{Previous work}

Recently, Kent et al. (2002) suggested "that the distinct paleomagnetic feature with negative inclinations at Mono Lake [the MLE] is correlative with the Laschamp excursion." Kent et al. (2002) based their conclusion on new age models for the Wilson Creek Formation using ${ }^{14} \mathrm{C}$ dates of acid-leached ostracode valves and ${ }^{40} \mathrm{Ar} /{ }^{39} \mathrm{Ar}$ age estimations of tephra. They assumed that ostracode ages represented minimum values and that ${ }^{40} \mathrm{Ar} /{ }^{39} \mathrm{Ar}$ ages represented maximum values. Kent et al. (2002) concluded that the age of Ash \#15 "most probably occurred between 38 and $41 \mathrm{ka}$ " and that this range overlapped "available age constraints for the Laschamp excursion"

${ }^{14} \mathrm{C}$ values of samples of inorganic carbon are subject to three sources of error: (1) incorporation of old carbon during precipitation of the sample (reservoir effect), (2) mixing of reworked old carbonate with the sample, (3) and incorporation of modern carbon after subaerial exposure of the sample. Kent et al. (2002) did not remove reworked ostracodes, assumed a reservoir effect of $1000 \mathrm{yr}$, and minimized modern carbon contamination. Benson et al. (1990) showed that carbonates deposited in the Mono Basin during the past $650 \mathrm{cal} \mathrm{yr}$ exhibit a reservoir effect ranging from 1100 to $5300 \mathrm{yr}$. Thus, the ${ }^{14} \mathrm{C}$ dates of Kent et al. (2002) are most likely overestimates of time of deposition.

\section{The age of Ash $\# 15$ in the Pyramid Lake Basin}

Sediments within the Pyramid Lake Basin offer an opportunity for obtaining accurate and precise ${ }^{14} \mathrm{C}$ age estimates of Ash \#15. Dates that relate to the age of Ash \#15 have been obtained on samples of organic carbon contained in lacustrine sediments from three sites within the Pyramid Lake Basin. The total organic carbon (TOC) fraction in the Pyramid Lake Basin is mostly composed of algae that obtain their carbon from dissolved $\mathrm{CO}_{3}^{2-}$ and $\mathrm{HCO}_{3}^{-}$. Therefore, ${ }^{14} \mathrm{C}$ dates obtained from the TOC fraction will reflect the reservoir effect in Pyramid Lake, but will not reflect later addition of modern carbon. During the past $3000 \mathrm{yr}$, the Pyramid Lake reservoir effect has been $\sim 600 \mathrm{yr}$ (Benson et al., 2002)

Liddicoat $(1992,1996)$ determined the position of the upper half of the MLE in outcrops within the Pyramid Lake (Pyramid Island and Pelican Point) (Fig. 1A). In 1992, Benson et al. (1997) obtained a core (PLC92B) from Wizards Cove (Fig. 1A). The Trego Hot Springs (THS) and Wono tephra were found 5.07 and $7.90 \mathrm{~m}$ below the sediment-water interface and a third tephra, believed to be the Timber Lake tephra, was found at a depth of $8.50 \mathrm{~m}$ (Fig. 1B). Sediments above the Wono tephra in PLC92B and at the Pyramid Island site show evidence of shallow-water conditions and subaerial exposure (Figs. 7 and 8 in Benson et al., 1997). This suggests that the rate of sedimentation between the deposition of the THS and Wono tephra was not constant and should not be used to assign ages to higher or lower intervals at these sites. The Wono tephra was deposited in shallow water at the Agency Bridge site 

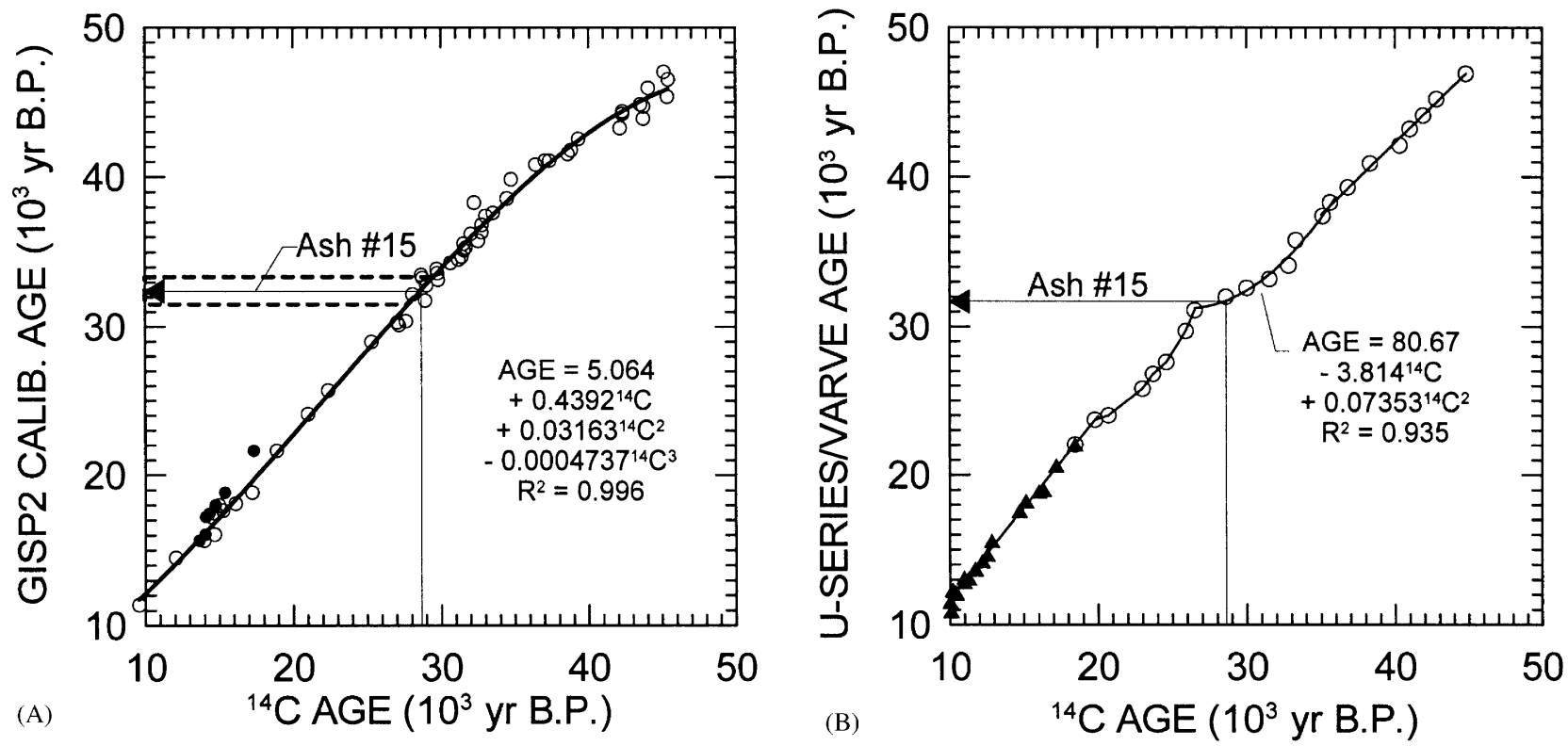

Fig. 2. (A) Polynomial fit to the core PS2644 calibration data set of Voelker et al. (1998). Open circles are data from planktonic foraminifera; filled circles are from benthic foraminifera (not used in the fit). The thin solid line shows the conversion of the ${ }^{14} \mathrm{C}$ age of Ash $\# 15$ to GISP2 yr. The heavy dashed lines enclose the MLE interval. (B) Polynomial fit to the calibration data of Bard et al. (1998) (black diamonds) and Kitagawa and van der Plicht (1998) (open circles). The thin solid line shows the conversion of the ${ }^{14} \mathrm{C}$ age of Ash $\# 15$ to varve-calibrated yr.

(elevation $1203 \mathrm{~m}$ a.s.1.) located southeast of Pyramid Lake (Fig. 1A). Thus it was deposited in $61 \mathrm{~m}$ of water at the Wizards Cove site and in $43 \mathrm{~m}$ of water at the Pyramid Island and Pelican Point sites. Sediments between the Timber Lake and Wono tephra generally indicate fairly deep water conditions (Benson et al., 1997). We, therefore, elected to use age controls located below the Wono tephra to calculate ages of the Timber Lake and Ash \#15 events.

Three raw ${ }^{14} \mathrm{C}$ ages from core PLC92B at depths of $8.58,9.68$, and $11.92 \mathrm{~m}$ were extrapolated to obtain Timber Lake tephra $\left(28,120 \pm 300{ }^{14} \mathrm{C}\right.$ yr BP $)$ and Wono tephra $\left(27,370 \pm 300{ }^{14} \mathrm{C}\right.$ yr BP) ages (Fig. 1C). The ages of the two tephra were then used to estimate the age of the Ash $\# 15\left(28,620 \pm 300{ }^{14} \mathrm{C}\right.$ yr BP $)$ at the Pyramid Island site. The amount of sediment that accumulated between the Wono and Timber Lake events was identical at both sites, indicating similar sedimentation rates (Fig. 1B).

We also used the ages of the Wono and Timber Lake tephra to estimate the age $\left(28,870 \pm 300{ }^{14} \mathrm{C} \mathrm{yr} \mathrm{BP}\right)$ of the $1.6 \mathrm{~m}$ organic-rich sediment sample from the Pyramid Island site. This material had been previously dated at $29,000 \pm 980{ }^{14} \mathrm{C}$ yr BP by Davis (1983), supporting the validity of the constant sedimentation rate model. We also accomplished a less rigorous estimation of the age of the Ash $\# 15\left(28,880 \pm\right.$ ? ${ }^{14} \mathrm{C}$ yr) at the Pelican Point site using the age of the Wono tephra and assuming that the Pelican Point and Pyramid Island sedimentation rates were identical; i.e., $0.080 \mathrm{~cm} \mathrm{yr}^{-1}$. Two different approaches were used to convert the most accurate ${ }^{14} \mathrm{C}$ age estimate of Ash $\# 15$ to calibrated years. The Voelker et al. (1998) calibration (Fig. 2A) was used to calculate an age of 32,400 GISP2 yr BP for Ash $\# 15$. The newer calibration set from Voelker et al. (2000) does not differ significantly from the Voelker et al. (1998) data set within the age range of interest. We also used the Kitagawa and van der Plicht (1998) (Fig. 2B) varve-based chronology to calculate a date of 31,700 cal yr BP for Ash \#15; however, this date is not relative to the GISP2 time scale and should not be used for comparison with GISP2-based ages. The varvebased age of the MLE may be comparable to isotopebased age estimations, in which case the varve-based calibrated age of Ash $\# 15$ is shown to be significantly younger than isotope-based ages of the Laschamp excursion.

A calculation using calibrated (Voelker et al., 1998) ${ }^{14} \mathrm{C}$ dates that bracket Ash $\# 15$ in the Mono Basin and the distance between the dated levels indicates that the MLE occurred over approximately an $1800 \mathrm{yr}$ time interval. The Voelker et al. (1998) calibrated age of Ash \#15 and the duration of the MLE indicate that the MLE occurred between 31,500 and 33,300 GISP 2 yr BP. The Voelker et al. (1998, 2000)-based dates for the MLE are within the upper range of the relative paleomagnetic intensity low $(31,000$ to 33,500 GISP2 yr BP) that has been recognized within the NAPIS-75 stack as the MLE. In addition, the GISP2 age of the upper MLE at the Pyramid Island site is only slightly younger than the ${ }^{36} \mathrm{Cl}$ anomaly ( $\sim 33,400$ to $\sim 34,500$ GISP2 yr BP) found in GISP2 and the intensity low $(\sim 33,700$ to $\sim 34,600$ 
GISP2 yr BP) found in marine core PS2644 (Voelker et al., 2000), all of which have been associated with the MLE.

\section{The Mono Lake excursion in the Summer Lake Basin}

Negrini et al. (2000) have shown that the Wono tephra lies above two paleomagnetic excursions in the Summer Lake Basin. They compared the younger excursion, which has an estimated ${ }^{14} \mathrm{C}$ age range of $\sim 27,300$ to $29,500{ }^{14} \mathrm{C}$ yr BP, with the Mono Lake inclination record and demonstrated it was equivalent to the excursion that brackets Ash \#15 in the Wilson Creek section.

We therefore conclude that the excursion that brackets Ash $\# 15$ is not the Laschamp excursion. Our best estimate of the age of Ash $\# 15$ (not corrected for reservoir effect) is $28,620 \pm 300{ }^{14} \mathrm{C}$ yr based on ${ }^{14} \mathrm{C}$ data from the Pyramid Lake Basin. This implies that the MLE occurred between 31,500 and 33,300 GISP2 yr BP, an age range consistent with its position in the NAPIS75 paleointensity stack (Laj et al., 2000). If the value of the late-Holocene reservoir effect in Pyramid Lake is applicable to the late-Pleistocene, Ash $\# 15$ has an age of $28,020 \pm 300{ }^{14} \mathrm{C}$ yr BP $(31,800$ GISP2 yr BP, Voelker et al., 1998), a value also consistent with the position of the MLE in the NAPIS-75 stack.

\section{An alternative calculation of the age of ash $\# 15$ using ${ }^{14} \mathrm{C}$ dates of leached ostracodes from the Wilson Creek section}

Ash $\# 15$ is located between leached ostracode samples that have ages of $33,400 \pm 580{ }^{14} \mathrm{C}$ yr $\mathrm{BP}$ and $30,510 \pm 360{ }^{14} \mathrm{C}$ yr BP Linear interpolation of the two dates yields an uncorrected ${ }^{14} \mathrm{C}$ age of $\sim 31,700{ }^{14} \mathrm{C}$ yr BP for Ash \#15. Application of the range of reservoir values (1100-5300 yr) associated with sediments deposited during the past $650 \pm \mathrm{yr}$, rather than the $1000 \mathrm{yr}$ value adopted by Kent et al. (2002), yields a reservoircorrected ${ }^{14} \mathrm{C}$ age range of $26,400-30,600{ }^{14} \mathrm{C}$ yr BP for Ash $\# 15$. This corresponds to 30,000 to 34,500 GISP2 yr (Voelker et al., 1998)(Fig. 2A) which is consistent with the age of the younger GRIP intensity low and ${ }^{36} \mathrm{Cl}$ anomaly ( $\sim 33,400$ to $\sim 34,500$ GISP2 yr) associated with the MLE but is clearly younger than the older intensity low and ${ }^{36} \mathrm{Cl}$ anomaly $(\sim 38,500$ to $\sim 43,000$ GISP2 yr) associated with the Laschamp excursion.

The $31,700{ }^{14} \mathrm{C}$ yr BP date (not corrected for reservoir effect) for Ash $\# 15$ based on an interpolation of the raw ${ }^{14} \mathrm{C}$ data of Kent et al. (2002) is $\sim 3100$ yr older than the age estimate for Ash $\# 15$ based on data from the Pyramid Lake Basin. This suggests that a reservoir effect of $\sim 3100 \mathrm{yr}$ (approximately the midpoint of the range of late-Holocene values) was characteristic of Mono Lake water at the time of deposition of Ash $\# 15$, and/or that reworked ostracodes containing "old" carbon may have been included in samples submitted for ${ }^{14} \mathrm{C}$ analyses by Kent et al. (2002).

\section{Acknowledgements}

We thank Dennis Kent and his co-authors for access to a preprint of their Earth and Planetary Sciences paper and also for his remarks on an earlier draft of this paper. Harry Leland, Eleanor Griffin, Robert Coe, and an anonymous reviewer provided helpful suggestions for the improvement of this paper.

\section{References}

Bard, E., Arnold, M., Hamelin, B., Tisnerat-Laborde, N., Cabioch, G., 1998. Radiocarbon calibration by means of mass spectrometric ${ }^{239} \mathrm{Th} /{ }^{234} \mathrm{U}$ and ${ }^{14} \mathrm{C}$ ages of corals: an updated database including samples from Barbados, Murroa and Tahiti. Radiocarbon 40, 1085-1092.

Benson, L.V., Currey, D.R., Dorn, R.I., Lajoie, K.R., Oviatt, C.G., Robinson, S.W., Smith, G.I., Stine, S., 1990. Chronology of expansion and contraction of four Great Basin lake systems during the past 35,000 years. Palaeogeography, Palaeoclimatology, Palaeoecology 78, 241-286.

Benson, L.V., Smoot, J., Kashgarian, M., Sarna-Wojcicki, A., Burdett, J.W., 1997. Radiocarbon ages and environments of deposition of the Wono and Trego Hot Springs tephra layers in the Pyramid Lake subbasin, Nevada. Quaternary Research 47, 251-260.

Benson, L.V., Lund, S.P., Burdett, J.W., Kashgarian, M., Rose, T.P., Smoot, J., Schwartz, M.D., 1998. Correlation of Late-Pleistocene lake level oscillations in Mono Lake, California, with North Atlantic climate events. Quaternary Research 49, 1-10.

Benson, L.V., Kashgarian, M., Rye, R.O., Lund, S.P., Paillet, F.L., Smoot, J., Kester, C., Mensing, S., Meko, D., Lindstrom, S., 2002. Holocene multidecadal and multicentennial droughts affecting northern California and Nevada. Quaternary Science Reviews 21, 659-682.

Coe, R.S., Liddicoat, J.C., 1994. Overprinting of natural magnetic remanence in lake sediments by a subsequent high-intensity field. Nature 367, 57-59.

Davis, J.O., 1978. Quaternary tephrochronology of the Lake Lahontan area, Nevada and California. Nevada Archeological Survey Research Paper No. 7, 137.

Davis, J.O., 1983. Level of Lake Lahontan during deposition of the Trego Hot Springs tephra about 22,400 years ago. Quaternary Research 19, 312-324.

Gillot, P.Y., Labeyrie, J., Laj, C., Valladas, G., Gurerin, G., Poupeau, G., Delibrias, G., 1979. Age of the Laschamp paleomagnetic excursion revisited. Earth and Planetary Science Letters 42, 444-450.

Hall, C.M., York, D., 1978. Age of the Laschamp geomagnetic polarity reversal. Nature 274, 462-464.

Kent, D.V., Hemming, S.R., Turrin, B.D., 2002. Laschamp excursion at Mono Lake? Earth and Planetary Science Letters 197, 151-164.

Kitagawa, H., van der Plicht, J., 1998. A 40,000-year varve chronology from Lake Suigetsu, Japan: extension of the ${ }^{14} \mathrm{C}$ calibration curve. Radiocarbon 40, 505-515. 
Laj, C., Kissel, C., Mazaud, A., Channell, J.E.T., Beer, J., 2000. North Atlantic palaeointensity stack since $75 \mathrm{ka}$ (NAPIS-75) and the duration of the Laschamp event. Philosophical Transactions of the Royal Society of London, Series A 358, $1009-1025$.

Liddicoat, J.C., 1992. Mono Lake excursion in Mono Basin, California, and at Carson Sink and Pyramid Lake, Nevada. Geophysical Journal International 108, 442-452.

Liddicoat, J.C., 1996. Mono lake excursion in the Lahontan basin, Nevada. Geophysical Journal International 125, 630-635.

Liddicoat, J.C., Coe, R.S., 1979. Mono Lake geomagnetic excursion. Journal of Geophysical Research 84, 261-271.

Negrini, R.M., Davis, J.O., Verosub, K.L., 1984. Mono Lake geomagnetic excursion found at Summer Lake, Oregon. Geology $12,464-643$.

Negrini, R.M., Erbes, D.B., Faber, K., Herrera, A.M., Roberts, A.P., Cohen, A.S., Wigand, P.E., Foit, F.F., 2000. A paleoclimate record for the past 250,000 years from Summer Lake, Oregon, USA: I. Chronology and magnetic proxies for lake level. Journal of Paleolimnology 24, 125-149.
Nowaczyk, N.R., 1997. High-resolution magnetostratigraphy of four sediment cores from the Greenland Sea-II. Rock magnetic and relative palaeointensity data. Geophysical Journal International 131, 325-334.

Nowaczyk, N.R., Knies, J., 2000. Magnetostratigraphic results from the eastern Arctic Ocean: AMS ${ }^{14} \mathrm{C}$ ages and relative palaeointensity data of the Mono Lake and Laschamp geomagnetic reversal excursions. Geophysical Journal International 140, 185-197.

Voelker, A.H., Sarnthein, M., Grootes, P.M., Erlenkeuser, H., Laj, C., Mazaud, A., Nadeau, M., Schleicher, M., 1998. Correlation of marine ${ }^{14} \mathrm{C}$ ages from the Nordic seas with the GISP2 isotope record: implications for ${ }^{14} \mathrm{C}$ calibration beyond $25 \mathrm{ka}$ BP. Radiocarbon 40, 517-534.

Voelker, A.H.M., Grootes, P.M., Nadeau, M., Sarnthein, M., 2000. Radiocarbon levels in the Iceland Sea from 25-53 kyr and their link to the Earth's magnetic field intensity. Radiocarbon 42, 437-452.

Wagner, G., Beer, J., Laj, C., Kissel, C., Masarik, J., Muscheler, R., Synal, H., 2000. Chlorine-36 evidence for the Mono Lake event in the summit grip ice core. Earth and Planetary Science Letters 181, $1-6$. 